\title{
Somatostatin content and receptors in the cerebral cortex of depressed and control subjects
}

\author{
BRUCE G CHARLTON, ALAN LEAKE, CAROLYN WRIGHT, \\ ANDREW F FAIRBAIRN, *IAN G MCKEITH, * JOHN M CANDY, I NICOL FERRIER \\ From the MRC Neuroendocrinology Unit, Newcastle General Hospital, and *St Nicholas Hospital, Gosforth, \\ Newcastle upon Tyne, UK
}

SUMMARY Somatostatin-like immunoreactivity is reduced in the cerebrospinal fluid in depression and this is presumed to reflect alterations in cerebral somatostatinergic systems. We have examined this hypothesis by measuring this immunoreactivity and somatostatin receptors in post-mortem cortical tissue from depressed patients and control subjects. There was no significant difference in the temporal and occipital cortex in somatostatin-like immunoreactivity or in somatostatin receptor affinity and binding capacity between depressed and control groups. It is concluded that there may not be an alteration of cortical somatostatin function in depression.

Somatostatin is present in both the central nervous system and peripheral tissues. It has a wide range of activities, inhibiting the secretion of many hormones, including growth hormone, and functioning as a neurotransmitter or neuromodulator. ${ }^{1}$ These effects have led to studies on the involvement of somatostatin in psychiatric illnesses. Somatostatin concentrations in cerebrospinal fluid (CSF) have been reported to be reduced in depression. ${ }^{2-5}$ This finding is not, however, specific to depression, as reduced levels have also been noted in anorexia nervosa, schizophrenia and senile dementia. ${ }^{25}$ CSF somatostatin is considered to derive from brain tissue, with contributions from a variety of regions (although the relative importance of different regions has not been established $^{3}$ ). Reduced CSF concentrations of somatostatin may be the result of reduced numbers of cerebral somatostatin-containing neurons, reduced release or an increased rate of elimination of somatostatin.

We have investigated somatostatin-like immunoreactivity (SLI) and somatostatin receptors in two cortical regions to establish whether there are changes in this system in depression.

Address for reprint requests: Dr I N Ferrier, MRC Neuroendocrinology Unit, Newcastle General Hospital, Newcastle upon Tyne, NE4 6BE, UK.

Received 27 October 1987.

Accepted 23 December 1987

\section{Methods}

\section{Subjects}

Depressed subjects had died of coincident physical illness while inpatients at a psychiatric hospital. A detailed description of subject selection is given by McKeith et al. ${ }^{6}$ Diagnosis was made using DSM III criteria for major depressive episode. ${ }^{7}$ Nine subjects were studied (six female, three male). One subject was in the depressed phase of a bipolar affective illness. In seven of these subjects there was clinical evidence of major depression within 2 weeks before death, the other two had depressed mood during this time. Seven subjects were sub-classified as having melancholia, three of these with psychotic features. Mean age was 73, 7 yr (mean, SD; range 63-84). Time interval between death and freezing of tissue (post-mortem delay) was 5-45 h (26, $13 \mathrm{~h}$; mean, SD). Subjects died of natural causes, principally from vascular disease. Two subjects were drug-free (for at least a month) at the time of death, one subject was taking benzodiazepines and the remainder were taking antidepressants. A global assessment of cognitive functioning (37 item mental test score $^{8}$ ) was available in most cases and was not in the range suggestive of dementia.

Control subjects had died in hospital from natural causes, principally vascular disease. Case notes were examined and subjects with a history of psychiatric illness or psychotropic medication were excluded. Seven subjects were studied (six female, one male; age 77, $6 \mathrm{yr}$; mean, SD). Post-mortem delay was 3-44 h ( 19, $26 \mathrm{~h}$; mean, SD).

\section{Brain dissection}

The brain was removed from the skull, the left hemisphere was coronally sliced and the sections were sealed in poly- 
thene, snap-frozen in arcton and stored at $-70^{\circ} \mathrm{C}$. Cortical grey matter was sub-dissected from the coronal slices at $-10^{\circ} \mathrm{C}$.

\section{Somatostatin assay}

Tissue from the temporal and occipital cortex was homogenised in $10 \%(\mathrm{w} / \mathrm{v}) 0.1 \mathrm{~mol} \mathrm{l}^{-1}$ hydrochloric acid $/ 0.005 \mathrm{~mol}$ $1^{-1}$ ascorbic acid. The mixture was heated to $80^{\circ} \mathrm{C}$ for 10 min, centrifuged $(12000 \mathrm{~g}, 10 \mathrm{~min})$ and the supernatent stored at $-20^{\circ} \mathrm{C}$. Prior to assay samples were thawed, recentrifuged under identical conditions, and neutralised using $1 \mathrm{~mol}^{-1}$ sodium hydroxide. Somatostatin-like immunoreactivity was measured using the radioimmunoassay method and reagents supplied by Amersham, UK. The antiserum recognised somatostatin 14,25 and 28 (somatostatin 14 was used as standard). Minimum detectable concentration of somatostatin was $3 \cdot 1 \mathrm{pmol}^{-1}$. All samples were measured in a single assay which had a coefficient of variation of $5 \%$. Protein was measured using the Bradford method $^{9}$ with BSA (RIA grade, Sigma) as standard. Results were expressed as fmol somatostatin $\mathrm{mg}$ protein $^{-1}$.

\section{Somatostatin receptor assay}

The method used for somatostatin receptor binding was essentially that described by Whitford et al. ${ }^{10}$ Brain tissue was weighed, homogenised using a Teflon/glass homogeniser in 10 volumes of ice cold buffer $1(50 \mathrm{mM}$ Tris- $\mathrm{HCl}, 10, \mathrm{mM}$

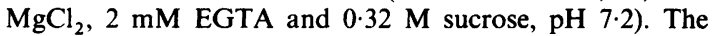
homogenate was centrifuged at $1000 \mathrm{~g}$ for $10 \mathrm{~min}\left(4^{\circ} \mathrm{C}\right)$ and the supernatant recentrifuged at $20000 \mathrm{~g}$ for $30 \mathrm{~min}\left(4^{\circ} \mathrm{C}\right)$. The resultant pellet was resuspended in buffer $2(50 \mathrm{mM}$ Tris- $\mathrm{HCl}, 10 \mathrm{mM} \mathrm{MgCl}, 2 \mathrm{mM}$ EGTA, $0.1 \% \mathrm{w} / \mathrm{v}$ BSA, aprotinin $\left(100 \mathrm{KIU} \mathrm{ml}^{-1}\right)$ and bacitracin $\left(10 \mathrm{U} \mathrm{ml}^{-1}\right), \mathrm{pH}$ $7 \cdot 2)$. Receptor binding was determined by incubating $0 \cdot 1$ nmol $1^{-1}\left({ }^{125} \mathrm{I}\right)$ Somatostatin-14 $\left(\mathrm{tyr}^{11}\right)$ (Amersham, $2100 \mathrm{Ci}$ $\mathrm{mmol}^{-1}$ ) in the presence of 0.025 to $0.8 \mathrm{nmol}^{-1}$ unlabelled somatostatin-14 with $50-100 \mu g$ membrane protein in a final incubation volume of $200 \mu \mathrm{l}$. The incubation was allowed to proceed for $30 \mathrm{~min}$ at $30^{\circ} \mathrm{C}$. Non-specific binding was assessed by addition of $\mu 1 \mathrm{~mol} \mathrm{l}^{-1}$ unlabelled somatostatin-14. The reaction was terminated by centrifugation at $14000 \mathrm{~g}$ for $3 \mathrm{~min}$ and the resultant pellet washed with $1 \mathrm{ml} 50 \mathrm{mM}$ Tris- $\mathrm{HCl}, 0.01 \%(\mathrm{v} / \mathrm{v})$ Triton $\mathrm{X}-100, \mathrm{pH} \mathrm{7 \cdot 2}$. The radioactivity associated with the pellets was measured in a gamma counter at $78 \%$ efficiency. Binding capacity and affinity was determined by Scatchard analysis. ${ }^{11}$ The subsequent plot was found to be linear across the range of concentrations employed, indicating the presence of only one high affinity binding site under these conditions. ${ }^{10}$

\section{Results}

Results for temporal and occipital cortices are shown in the table.

SLI showed no significant difference between depressed and control subjects in either cortical region ( $\mathrm{p}>0.05$, Student's $t$ test). SLI in the temporal region was higher than in the occipital region $(p<$ 0.001 for combined groups, Student's $t$ test).

Somatostatin receptor affinity in depressed and control groups was not significantly different, or
Table Somatostatin concentrations, somatostatin receptor affinity ( $K d)$ and somatostatin receptor binding (Bmax). Mean, standard deviation.

\begin{tabular}{|c|c|c|c|}
\hline & \multirow{2}{*}{$\begin{array}{l}\text { Somatostatin } \\
\text { concentration } \\
\text { (fmol } \mathrm{mg}^{-1} \text { ) }\end{array}$} & \multicolumn{2}{|c|}{ Somatostatin receptor } \\
\hline & & $K d\left(\mathrm{nmol} \mathrm{l}^{-1}\right)$ & $\left(f m o l m g^{-1}\right)$ \\
\hline $\begin{array}{l}\text { Temporal cortex } \\
\text { Depressed subjects } \\
\text { Control subjects } \\
\text { Occipital cortex }\end{array}$ & $\begin{array}{l}605,195 \\
400,245\end{array}$ & $\begin{array}{l}0.30,0 \cdot 17 \\
0.35,0.20\end{array}$ & $\begin{array}{l}49,24 \\
47,28\end{array}$ \\
\hline $\begin{array}{l}\text { Depressed subjects } \\
\text { Control subjects }\end{array}$ & $\begin{array}{l}198,105 \\
215,126\end{array}$ & $\begin{array}{l}0 \cdot 32,0 \cdot 17 \\
0 \cdot 27,0 \cdot 12\end{array}$ & $\begin{array}{l}35,26 \\
27,12\end{array}$ \\
\hline
\end{tabular}

between different brain regions ( $p>0 \cdot 05$, Student's $t$ test). No significant correlation was observed between age or post-mortem delay, and either SLI or receptor binding in the cortical regions studied ( $p>0.05$, Kendall's rank correlation test).

\section{Discussion}

The absence of change in either SLI or receptor status of somatostatin is evidence that this system is not altered in the occipital or temporal cortex in depression. This conclusion is supported by a previous study in the frontal cortex (using the same post-mortem subjects) where we found no difference in SLI between depressed and control subjects. ${ }^{12}$ Similarly we have found no difference in SLI between suicide subjects ( $\mathrm{n}$ $=12$ ) (retrospectively diagnosed as having a depressive illness) and controls, $(n=12)$, in a study of frontal, motor, parietal and temporal cortex. ${ }^{13} \underset{p}{\infty}$ Although the group sizes are relatively small these results suggest that there is no significant change in somatostatin in the cerebral cortices in depression and that reduced CSF concentrations are therefore unlikely to reflect an alteration in cortical somatostatin-containing systems. Altered CSF levels may be due to changes in areas such as the hypothalamus or parts of the limbic system which contain high levels of somatostatin and lie near to the ventricular system. ${ }^{10}$

These data contrast with the results described by some workers for Alzheimer-type dementia (ATD) where reduced CSF somatostatin ${ }^{5}$ is accompanied by reduced cortical somatostatin ${ }^{14}$ and reduced receptor binding ${ }^{15}$ in severely affected subjects. These postmortem results are controversial and may simply reflect cell loss. Other studies of ATD subjects have not demonstrated changes in either $\mathrm{SLI}^{16}$ or high affinity somatostatin receptor density. ${ }^{10}$

While neurochemical measurements in postmortem brain have the advantage over CSF measurements of being a more direct measure of neurotransmitter status, there are several ways such as post-mortem delay when neurotransmitters and/or receptors may be degraded. However, most peptides, 
including somatostatin, appear to be stable for considerable periods after death. ${ }^{17}$ The lack of correlation between post-mortem delay and the measures of somatostatin and its receptors indicates that degradation is unlikely to be a serious problem in the present study. No effect of age was noted. However, there were insufficient drug-free subjects to allow statistical analysis of medication effects, and it would be desirable to replicate this study using drug-free subjects.

To conclude, the results of this study, and of our previous studies of other cortical regions, imply that cortical somatostatin function is unlikely to be altered in depression. However, post-mortem measurements can only provide clues to alterations in neurotransmitter activities; full assessment awaits the development of techniques for assessing their function in the living subject.

Thanks are due to Mrs H Flett for typing the manuscript. Dr Charlton was funded by the Wellcome trust.

\section{References}

1 Bloom S, Polak JM. Somatostatin. Br Med J 1987;295: 288-9.

2 Gerner RH, Yamada T. Altered neuropeptide concentrations in cerebrospinal fluid of psychiatric patients. Brain Res 1982;238:298-302.

3 Rubinow DR, Gold PW, Post RM, et al. Somatostatin in affective illness. Arch Gen Psychiatry 1983;40: 409-12.

4 Doran AR, Rubinow DR, Roy A, Pickar D. CSF somatostatin and abnormal response to dexamethasone administration in schizophrenic and depressed patients. Arch Gen Psychiatry 1986;43: 365-69.

5 Bissette G, Widerlow E, Wallens $\mathrm{H}$, et al. Alterations in cerebrospinal fluid concentrations of somatostatin- like immunoreactivity in neuropsychiatric disorders. Arch Gen Psychiatry 1986;43:1148-51.

6 McKeith IG, Marshall EF, Ferrier IN, et al. 5-HT receptor binding in post-mortem brain from patients with affective disorder. J Affective Disord 1987;13: 67-74.

7 APA DSM-III Diagnostic and Statistical Manual of Mental Disorders. 3rd ed. Washington DC, APA 1980.

8 Blessed G, Tomlinson BE, Roth M. The association between quantitive measures of dementia and of senile changes in the cerebral gray matter of elderly subjects. $B r J$ Psychiatry 1968;114:797-811.

9 Bradford MM. A rapid and sensitive method for the quantitation of microgram quantities of protein utilizing the principle of protein dye binding. Anal Biochem 1976;72:248-54.

10 Whitford CA, Bloxham CA, Snell CR, Candy JM, Hirst BH. Regional distribution of high-affinity $\left[{ }^{3} \mathrm{H}\right]$-somatostatin binding site in the human brain. Brain Res 1986;398:141-47.

11 Scatchard G. The attraction of proteins for small molecules and ions. Ann NY Acad Sci 1949;51:660-72.

12 Ferrier IN, McKeith IG, Charlton BG, et al. In: Lerer B, Gershon S, eds. New Directions in Affective Disorders. New York. Springer Verlag. (In press).

13 Charlton BG, Wright C, Leake A. Somatostatin immunoreactivity in post mortem brain from depressed suicides. Arch Gen Psychiatry (in press).

14 Davies P, Katzman R, Terry RD. Reduced somatostatin-like immunoreactivity in cerebral cortex from cases of Alzheimer's disease and Alzheimer senile dementia. Nature 1980;288:279-80.

15 Beal MF, Mazwek MF, Tran VT, Chaltha G, Bird ED, Martin JB. Reduced numbers of somatostatin receptors in the cerebral cortex in Alzheimer's disease. Science 1985;229:289-91.

16 Candy JM, Gascoigne AD, Biggins JA, et al. Somatostatin immunoreactivity in cortical and some subcortical regions in Alzheimer's disease. J Neurol Sci 1985;71:315-23.

17 Edwardson JA, McDermott JR. Neurochemical pathology of brain peptides. Br Med Bull 1983; 38:359-64. 